ISSN 1991-8631

Original Paper

http://indexmedicus.afro.who.int

\title{
Earthworm survival in used engine oil contaminated soil spiked with manure
}

\author{
Alewo Opuada AMEH ${ }^{1 *}$, Ibrahim Ali MOHAMMED-DABO ${ }^{2}$, Sani IBRAHIM ${ }^{3}$, \\ Joseph Baba AMEH ${ }^{4}$, Charles Danjuma AZIENGE ${ }^{5}$ and Yahuza TANIMU ${ }^{6}$ \\ ${ }^{1,2,5}$ Department of Chemical Engineering, Ahmadu Bello University, Zaria. \\ ${ }^{3}$ Department of Biochemistry, Ahmadu Bello University, Zaria. \\ ${ }^{4}$ Department of Microbiology, Ahmadu Bello University, Zaria. \\ ${ }^{6}$ Department of Biological Sciences, Ahmadu Bello University, Zaria. \\ ${ }^{*}$ Corresponding author, E-mail: alewooameh@yahoo.com
}

\begin{abstract}
Oil pollution is a worldwide prevalent threat to environmental sustainability and the remediation of oil contaminated soils, sediments, surface and underground water is a major challenge for environmental research. Earthworms are an important component of the soil biota and their response to oil pollution needs to be better understood when they are considered for use in bioremediation. Laboratory investigations were undertaken to monitor the survival rate of earthworms (Lumbricus terrestris Lin.) in soils contaminated with used engine oil sourced from three different engines (Motorcycle, Motorcar and Truck engines). The aim was to investigate the effect of used engine oil concentration, in soil, on the survival of earthworms (L. terrestris). The ability of $L$. terrestris to survive in bioremediated used engine oil contaminated soil was evaluated and it was observed that $100 \%$ of earthworms survived in both motorcycle and truck engine used engine oil contaminated soil for concentration as high as $150 \mathrm{~g}$ used engine oil $/ \mathrm{kg}$ soil for a period of 30 days. The highest tolerable concentration of the motorcar used engine oil contaminated soil by the worms was found to be $10 \mathrm{~g}$ used engine oil/kg soil.

(C) 2011 International Formulae Group. All rights reserved.
\end{abstract}

Keywords: Cow dung, Lumbricus terrestris, Poultry manure, Silt-loam, Used engine oil concentration.

\section{INTRODUCTION}

Earthworms are associated with a healthy soil and their absence is an indication of poor soil health. Earthworms have been used in environmental risk assessment as good indicator organisms for toxicity (Shin and Kim, 2001). Information on sensitivity of earthworms to oil-contaminated soil or their ability to survive in bioremediated soil is limited (Salanitro et al., 1997; Dorn and Salanitro, 2000). Neuhauser et al. (1989) reported that an oily sludge contaminated soil of concentrations $1.0-2.5 \%$ resulted in declines in biomass of Allolobophora tuberculata and Lumbricus terrestris (Lin.) to less than half of the untreated soil. The biomass of the treated plots remained lower than the untreated control plots for more than 2 years. In their investigation with Eisenia fetida (Savigny), Salanitro et al. (1997) reported that earthworms were unable to survive in soil for 2 weeks after contamination with $5 \%$ crude oil. Safwat et al. (2002) in their study, using crude oil contaminated soil, 
reported that an oil content of $0.5 \%$ was not harmful to the survival of earthworms for 7 days but an oil concentration of $1.5 \%$ reduced survival to less than $40 \%$ also, bioremediated soil containing $1.2 \%$ oil did not reduce survival of L. terrestris for 10 days.

In the bioremediation of petroleum hydrocarbon contaminated soil using organic amendment, the nature and concentration of organic amendment are important as they influence process parameters such as carbon/nitrogen ratio, $\mathrm{pH}$, microbial count, etc. When earthworms are used for bioremediation, the organic amendment used becomes even more important: in addition to the above mentioned parameters, the organic amendment becomes food for the worms. When investigating total petroleum hydrocarbons (TPH) losses in with-earthworm systems that either had or had not received food, Schaefer et al. (2005) noted that residual TPH in the with-food systems was greater. Maike and Filser (2007) reported that despite high mortality, earthworms may trigger degradation process and might therefore, be applied in the remediation of oil contaminated soil with moderate total petroleum hydrocarbon (TPH) concentrations $\quad(<4000$ $\mathrm{mg} / \mathrm{kg}$ ). They also reported that the extent of degradation was dependent on earthworm specie type. Callaham et al. (2002) on the other hand observed no difference in TPH concentrations associated with E. fetida. Earthworm activity has been reported to influence soil microbial activity, structure, $\mathrm{pH}$, carbon/nitrogen ratio, etc. (Hickman and Reid, 2008). It is thought that soils might benefit from earthworm introduction in terms of reduced contaminant concentrations as well as improved soil 'health' (EU Soil Framework Directive, 2006).

In some developing countries, used engine oil is dumped carelessly into the environment: in Nigeria, about 20 million gallons of waste engine oil are generated annually from mechanic workshops and discharged carelessly into the environment (Adegoroye, 1997). Bamiro and Osibanjo
(2004) put used engine oil generation in Nigeria at about 200 million liters per annum. One liter of used engine oil is enough to contaminate one million gallons of freshwater (USEPA, 1996). For earthworms to be used in the bioremediation of used engine oil contaminated soil, the concentration of used engine oil in soil which earthworm can tolerate has to be determined. This has not been reported.

The aim of this work was to investigate the effect of used engine oil concentration from motorcar (petrol engine), motorcycle (petrol engine) and a truck (diesel engine) on the survival of earthworms, Lumbricus terrestris.

\section{MATERIALS AND METHODS \\ Collection of samples}

Used engine oil uncontaminated soil was collected from the farmland of Ahmadu Bello University, Zaria, in clean plastic containers.

Mature earthworms lumbricus terrestris, ranging in weight from 0.3 to 0.5 $\mathrm{gm}$ each, were collected from the soil of Ahmadu Bello University, Zaria, identified in the Department of Biological Sciences and used for study within 72 hours after collection.

Poultry manure and cattle dung were collected from the National Animal Production and Research Institute (NAPRI), Ahmadu Bello University, Zaria.

\section{Physicochemical property determination for soil and manure}

Physicochemical properties determined for soil included $\mathrm{pH}$, water holding capacity, textural class as well as carbon, nitrogen and phosphorus content. The manures were also analysed for carbon, nitrogen and phosphorus content.

\section{Soil pH determination}

$10 \mathrm{~g}$ of sieved $(\leq 5 \mathrm{~mm})$ and air-dried soil was weighed into a $50 \mathrm{ml}$ beaker and 25 $\mathrm{ml}$ of distilled water added. The content was 
stirred manually for 30 minutes with a glass rod and left to stand for 1 hour. The electrode of the $\mathrm{pH}$ meter (Kent EIL 7055) was then inserted and the $\mathrm{pH}$ determined.

\section{Determination of water holding capacity (WHC)}

Six (6) inches of soil was placed in percolation tube and compacted by gentle bouncing. Water was added until the water level stood at about 2 inches above soil level. The tube was covered and left to stand for 2 days. After this period, the top half-inch of soil was discarded and wet soil was weighed into a pre-weighed evaporating dish. The sample was placed in oven at $110{ }^{\circ} \mathrm{C}$ for $24 \mathrm{~h}$. It was then removed and weighed to obtain bone dry weight of the sample. Percent water holding capacity was calculated as (Srivastava and Thakur, 2006):

Yowater holding capacity $=\frac{\text { wetweight-bone dry weight }}{\text { bone dry weight }}$ 1

\section{Textural class, $\mathbf{C}, \mathbf{N}$ and $\mathbf{P}$ content}

Soil textural class, as well as soil and manure carbon, nitrogen and phosphorus contents were analyzed at the Institute of Agricultural Research (IAR) Ahmadu Bello University, Zaria. Soil textural class was determined using the hydrometer method (Gee and Bauder, 1986). The organic carbon, phosphorus and nitrogen contents were determined according to the method of AOAC (2005).

\section{Earthworm survival assessment}

The test substrates were prepared according to the ISO guidelines for earthworm toxicity testing (ISO 11268-1, 1993). The soil sample collected was sieved $(\leq 5 \mathrm{~mm})$ to remove coarse stones and to homogenize. $1 \mathrm{~kg}$ of soil was weighed into plastic test containers. The soil was made up to $60 \%$ water holding capacity using deionised water. The soil samples were contaminated with various concentrations of the motorcycle used engine oil (UEO) $(5,10,20,30,40,100$ and
$150 \mathrm{~g}$ per $\mathrm{kg}$ of soil). The mixture was thoroughly mixed manually, (it is worth noting that all samples were prepared in duplicates). $5 \mathrm{~g}$ of poultry manure were then added and mixed and $1 \mathrm{~g}$ littered on the surface. Ten earthworms (Lumbricus terrestris) each were introduced into the containers and the weight of each test container recorded. At intervals of time (after every 3 days), the number of living earthworms in each container was recorded. The moisture content of $60 \%$ water holding capacity was maintained throughout the test period by weighing, to determine moisture loss, and adding make up deionised water when necessary. The samples were monitored for a total of 30 days. This procedure was repeated using cow dung in place of poultry manure. The above procedure was repeated for used engine oil collected from motorcar and diesel engines.

The effect of organic amendment (poultry manure) on the survival of the worms was also investigated. Three samples of used engine oil (from motorcycle) contaminated soil were prepared and 10 earthworms were introduced into each. The first sample (sample A) contained $100 \mathrm{~g} \mathrm{UEO} / \mathrm{kg}$ of soil and $100 \mathrm{~g}$ poultry manure $/ \mathrm{kg}$ of soil, the second sample (sample B) contained $100 \mathrm{~g} \mathrm{UEO} / \mathrm{kg}$ of soil with no poultry manure and the third sample (sample C) contained $0 \mathrm{~g} \mathrm{UEO} / \mathrm{kg}$ of soil and $100 \mathrm{~g}$ poultry manure $/ \mathrm{kg}$ of soil. The samples had their moisture contents adjusted to $60 \%$ water holding capacity. All samples where produced in duplicates and observed for 48 hours.

\section{RESULTS}

Analysis of soil

The physicochemical properties of the soil and manure are presented in Table 1.

\section{UEO from motorcycle and truck (diesel engine vehicle)}

Table 2 shows the survival of $L$. terrestris over time for various concentrations of UEO contaminated soil. The table shows 
that earthworm survival remained $100 \%$ throughout the period of the study (30 days).

\section{UEO from motorcar}

The survival of $L$. terrestris in soil treated with used engine oil from motorcar is presented in Table 3. As shown, UEO concentration greater than $10 \mathrm{~g} / \mathrm{kg}$ soil is lethal to the earthworms.

The effect of poultry manure concentration on worm survival in UEO contaminated soil

The result of this investigation is presented in Table 4.

Table 1: Physicochemical Property Determination of Soil and Manure.

\begin{tabular}{lccc}
\hline Properties & Soil & Cow dung & Poultry manure \\
\hline Nitrogen content $(\boldsymbol{\%})$ & 0.11 & 1.14 & 2.98 \\
Carbon content $(\boldsymbol{\%})$ & 1.26 & 56.65 & 45.58 \\
Phosphorus content $(\boldsymbol{\%})$ & 1.68 & 1.87 & 1.90 \\
pH & 6.7 & - & - \\
Textural class & Silt Loam & - & - \\
WHC (g/kg bone dry soil) & 0.41 & - & - \\
\hline
\end{tabular}

Table 2: Effect of UEO concentration from motorcycle/diesel engine vehicles (truck) on the survival of earthworms in soil spiked with poultry manure/cow dung.

\begin{tabular}{lccccc}
\hline \multicolumn{5}{c}{ \% survival of 10 earthworms (Lumbricus terrestris) } \\
\hline $\begin{array}{l}\text { g UEO/kg } \\
\text { soil }\end{array}$ & After 2 days & After 9 days & $\begin{array}{c}\text { After 16 } \\
\text { days }\end{array}$ & $\begin{array}{c}\text { After 23 } \\
\text { days }\end{array}$ & $\begin{array}{c}\text { After 30 } \\
\text { days }\end{array}$ \\
\hline $\mathbf{5}$ & & 100 & 100 & 100 & 100 \\
$\mathbf{1 0}$ & 100 & 100 & 100 & 100 & 100 \\
$\mathbf{2 0}$ & 100 & 100 & 100 & 100 & 100 \\
$\mathbf{3 0}$ & 100 & 100 & 100 & 100 & 100 \\
$\mathbf{4 0}$ & 100 & 100 & 100 & 100 & 100 \\
$\mathbf{5 0}$ & 100 & 100 & 100 & 100 & 100 \\
$\mathbf{1 0 0}$ & 100 & 100 & 100 & 100 & 100 \\
$\mathbf{1 5 0}$ & 100 & 100 & 100 & 100 & 100 \\
\hline
\end{tabular}

Table 3: Effect of UEO concentration from motorcar on the survival of earthworms in soil spiked with poultry manure/cow dung.

\begin{tabular}{lccccc}
\hline \multicolumn{5}{c}{ \% survival of 10 earthworms (Lumbricus terrestris) } \\
\hline $\begin{array}{l}\text { g UEO/kg } \\
\text { soil }\end{array}$ & After 2 days & After 9 days & $\begin{array}{c}\text { After 16 } \\
\text { days }\end{array}$ & $\begin{array}{c}\text { After 23 } \\
\text { days }\end{array}$ & After 30 days \\
\hline $\mathbf{5}$ & & 100 & 100 & 100 & 100 \\
$\mathbf{1 0}$ & 100 & 100 & 100 & 100 & 100 \\
$\mathbf{2 0}$ & 100 & 0 & 0 & 0 & 0 \\
$\mathbf{3 0}$ & $50 \pm 10$ & 0 & 0 & 0 & 0 \\
$\mathbf{4 0}$ & 0 & 0 & 0 & 0 & 0 \\
$\mathbf{5 0}$ & 0 & 0 & 0 & 0 & 0 \\
$\mathbf{1 0 0}$ & 0 & 0 & 0 & 0 & 0 \\
$\mathbf{1 5 0}$ & 0 & 0 & 0 & 0 & 0 \\
\hline
\end{tabular}


Table 4: The effect of poultry manure concentration on the survival of earthworms in used engine oil contaminated soil.

\begin{tabular}{lcc}
\hline Sample & UEO $(\mathbf{g}):$ manure $(\mathbf{g})$ :Soil $(\mathbf{k g})$ & Earthworm survival after 48 hours, \% \\
\hline A & $50: 50: 1$ & 0 \\
B & $50: 0: 1$ & 100 \\
C & $0: 50: 1$ & 100 \\
\hline
\end{tabular}

\section{DISCUSSION}

As shown in Table 1, the soil sample was found to contain $0.105 \%$ Nitrogen, $1.260 \%$ Carbon and $1.680 \%$ Phosphorus. The $\mathrm{pH}$ of the soil was found to be 6.7. The textural class of the soil was determined to be silt-loam. The property of the manure was found to be consistent with values obtained from literature (Marsh and Campling, 1970; Amanullah, 2007).

\section{UEO from motorcycle and truck (diesel engine vehicle)}

From Table 2, it can be seen that for all the concentrations considered (up to $150 \mathrm{~g}$ $\mathrm{UEO} / \mathrm{kg}$ soil which is $15 \%$ ), $100 \%$ of the earthworm survived for 30 days. Cast formation as a result of earthworm's activities was also observed at low UEO contamination levels. The observed quantity of cast was found to decrease with increase in UEO concentration. At very high UEO concentration ( $\geq 100 \mathrm{~g} / \mathrm{kg}$ ), no cast formation was observed, earthworms were found to lie on or around the soil and not enter it. This result suggests that used engine oil contaminated soil is not as toxic as crude oil to earthworms in comparison with the findings of Saterbak et al. (1999) and Safwat et al. (2002) for which earthworm mortality was $100 \%$ for concentrations $\leq 2.5 \%$. For the purposes of bioremediation therefore, a higher concentration of petroleum hydrocarbon contaminated soil (as high as $15 \%$ ) may be treated using earthworms whereas for crude oil, only $0.4 \%$ petroleum hydrocarbon contaminated soil may be treated with earthworms as reported by Maike and Filser (2007).

\section{UEO from motorcar}

After 2 days (as shown in Table 3), it was observed that $100 \%$ of Lumbricus terrestris survived in $5 \mathrm{~g} \mathrm{UEO} / \mathrm{kg}$ soil and 10 g UEO/kg soil, $50 \%$ survived in $20 \mathrm{~g}$ UEO/ $\mathrm{kg}$ soil and all died in the other samples (with higher UEO concentrations). It was further observed on day nine (9) that the survival of the earthworms in the $20 \mathrm{~g} \mathrm{UEO} / \mathrm{kg}$ soil had dropped to $0 \%$. For the $5 \mathrm{~g} \mathrm{UEO} / \mathrm{kg}$ soil and $10 \mathrm{~g} \mathrm{UEO} / \mathrm{kg}$ earthworm survival remained $100 \%$ up to 30 days. Cast formation was also observed for the 30 day period of study. This shows that concentrations above $10 \mathrm{~g} \mathrm{UEO} / \mathrm{kg}$ (that is $1 \%$ UEO) maybe lethal to earthworm, Lumbricus terrestris. Therefore, for the purpose of bioremediation of soil contaminated with used engine from motorcar, UEO concentration of less than $1 \%$ would be recommended when treatment with lumbricus terrestris is considered.

The death of the worms was probably due to one or a combination of the following factors: heavy metal content of the oil, presence of toxic petroleum hydrocarbons or the $\mathrm{pH}$ of the oil.

\section{The effect of poultry manure concentration}

The concentration of UEO and manure in sample A is typical of those used in bioremediation of oil contaminated soil (Adenipekun, 2008). As shown in Table 4, the quantity of organic amendment may also contribute to the environment being unfavourable for earthworm survival. All the worms in sample B and C were found to be alive after 48 hours whereas all the worms in sample A (which had a similar concentration of UEO with sample B and similar quantity of 
manure with sample C) died within 48 hours. Since the quantity of manure is important for bioremediation (in supplying nitrogen) as well to earthworm (as feed), further work needs to be done to determine and control the effect of manure (quantity/type) on earthworm survival in a bioremediation system.

The composition of used engine oil has been reported to be a function of: the composition of original crude oil, the refining process used, the additives, the efficiency and type of engine, the gasoline combustion products, the length of time in use (United States Department of Health and Human Services, 1997). Therefore, when earthworms are considered for use in the bioremediation of UEO contaminated soil, it is important to investigate the tolerance of earthworm for the contamination level of that soil as well as for the conditions for which bioremediation is to take place.

\section{Conclusions}

From the results obtained, the following conclusions can be drawn:

1. Earthworm (Lumbricus terrestris) was found to survive in UEO (sourced from a motorcycle and a truck engines) of concentrations up to the tune of $15 \%$ (wt/wt).

2. Concentrations of UEO from motorcar engine greater than $10000 \mathrm{mg} / \mathrm{kg}$ soil were found to be lethal to earthworm.

3. Lumbricus terrestris can be introduced in the bioremediation of used engine from motorcycles and truck engines of concentration up to $150 \mathrm{~g} \mathrm{UEO} / \mathrm{kg}$ soil, and from motorcar engines up to $10 \mathrm{~g} \mathrm{UEO} / \mathrm{kg}$ soil.

\section{ACKNOWLEDGEMENTS}

Authors thank the Science and Technology Education Post-Basic (STEP-B) Innovators of Tomorrow (IOT) and the University Board of Research (Ahmadu Bello University, Zaria) for their financial support.

\section{REFERENCES}

Adegoroye G. 1997. Environmental considerations in property design, urban development and renewal. In Dimensions of Environmental Problems in Nigeria, Akinjide $\mathrm{O}$ (ed). Friedrich Ebert Foundation: Washington; 12-25.

Adenipekun CO. 2008. Bioremediation of engine-oil polluted soil by Pleurotus tuber-regium Singer, a Nigerian white-rot fungus. African Journal of Biotechnology, 7(1): 055-058.

Amanullah MM. 2007. Nutrient Release Pattern during Composting Poultry Manure. Research Journal of Agriculture and Biological Sciences, 3(4): 306-308.

AOAC (Association of Official Analytical Chemists). 2005. Methods of Analysis. AOAC: Washington D. C.

Bamiro OA, Osibanjo O. 2004. Pilot study of used oils in Nigeria www.basel.int/ centers/proj_activ/stp_projects/04-03 (Accessed January, 2011).

Callaham MA, Stewart AJ, Alarcon C, McMillen SJ. 2002. Effects of earthworm (Eisenia fetida) and wheat (Triticum aestivum) straw additions on selected properties of petroleum contaminated soils. Environ Toxicol Chem, 21(8): 1658-1663.

Dorn PB, Salanitro JP. 2000. Temporal ecological assessment of oil contaminated soils before and after bioremediation. Chemosphere, 40: 419-426.

EU Soil Framework Directive, http://ec.europa.eu/environment/soil/inde x.htm, 2006.

Gee GW, Bauder JW. 1986. Particle-size analysis. In Methods of Soil Analysis (Part 1, 2nd edn), Klute A (ed). Agron. Monogr. 9. ASA and SSSA, Madison, WI; 383-411.

Hickman ZA, Reid BJ. 2008. Earthworm assisted bioremediation of organic contaminants. Environment International, 34: 1072-1081.

ISO International Standard 11268-1. 1993. Soil quality - Effects of pollutants on 
earthworms (Eisenia fetida) - Part 1: Determination of acute toxicity using artificial soil substrate. Internat. Org. f. Standard, Geneva.

Maike S, Filser J. 2007. The influence of earthworms and organic additives on the biodegradation of oil contaminated soil. Applied Soil Ecology, 36: 53 - 62.

Marsh R, Campling RC. 1970. Fouling of pastures by dung. Herb. Abstr., 40: $123-$ 130.

Neuhauser EF, Norton RA, Loehr RC, Sillman DY. 1989. Earthworm and soil microarthropod responses to oily waste application. Soil Biol. Biochem., 21: 275281.

Safwat H, Shakir H, Weaver RW. 2002. Earthworm survival in oil contaminated soil. Plant and Soil, 240: 127-132.

Salanitro JP, Dorn PB, Huesemann MH, Moore KO, Rhodes IA, Jackson LMR, Vipond TE, Western MM, Wisniewski HL. 1997. Crude oil hydrocarbon bioremediation and soil ecotoxicity assessment. Environ. Sci. Technol., 31: 1769-1776.

Saterbak A, Toy RJ, Wong DCL, McMain BJ, Williams MP, Dorn PB, Brzuzy LP, Chai EY, Salanitro JP. 1999. Ecotoxicological and analytical assessment of hydrocarbon-contaminated soils and application to ecotoxicological risk assessment. Environ. Toxicol. Chem., 18: 1591-1607.

Schaefer M, Peterson SO, Filser J. 2005. Effects of Lumbricus chlorotica and Eisenia fetida on microbial community dynamics in oil-contaminated soil. Soil Biol. Biochem., 37: 2065-2076.

Shin K, Kim K. 2001. Ecotoxicity monitoring of hydrocarbon-contaminated soil using earthworm (Eisenia foetida). Environmental Monitoring and Assessment, 70: 93-103.

Srivastava S, Thakur IS. 2006. Evaluation of bioremediation and detoxification potentiality of Aspergillus niger for removal of hexavalent chromium in soil microcosm. Soil Biology \& Biochemistry, 38: 1904-1911.

United States Department of Health and Human Services. 1997. Toxicological Profile for Used Mineral Based Crankcase Oil. Agency for Toxic Substances and Disease Registry, Division of Toxicology, Atlanta, GA.

USEPA. 1996. Recycling Used Oil: What Can You Do? Cooperation Extension Services ENRI-317: 1-2. 